\title{
AN INSIGHT INTO PROFESSIONAL REGISTRATION OF TECHNICAL PERSONNEL IN AERONAUTICAL ENGINEERING INDUSTRY
}

\author{
Devinder K. Yadav' ${ }^{1}$ Hamid Nikraz ${ }^{2}$ \\ Curtin University, Bentley Campus, Kent Street, Bentley, WA 6102, Australia \\ E-mail:dkharyanvi@yahoo.com.au (corresponding author)
}

Received 19 April 2012; accepted 11 May 2012

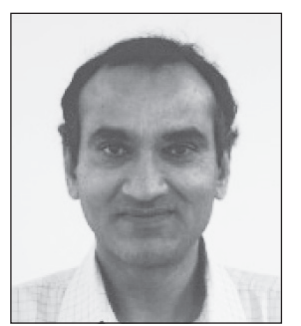

\begin{abstract}
Devinder K. YADAV
Education and affiliation: holds a master degree in aviation and he is associated with Curtin University, Australia. In addition to the academic qualifications, he also holds an aircraft engineer license with several ratings starting from Cessna 152 to wide-body Airbus and Boeing 747-400 aircraft and a pilot license.

Research interests: aeronautical engineering, airport engineering, aviation regulations, multidisciplinary engineering, and aviation management.
\end{abstract}

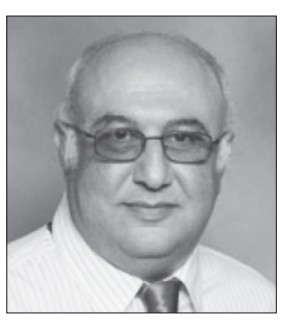

\section{Hamid NIKRAZ}

Education and affiliation: holds a doctorate degree in civil engineering and he is associated with Curtin University, Australia.

Research interests: civil engineering, pavement engineering, transportation and airport engineering, and multidisciplinary engineering topics.

\begin{abstract}
The aeronautical industry is a powerful force for progress in our modern global society. Industrial activities in this industry started to accelerate in the beginning of the $20^{\text {th }}$ century, and the number of aircraft in airspace for civil purposes started increasing. Consequently, the industry and the personnel associated with aircraft were required to be regulated to ensure the safety and reliability of the product. Currently, various categories of personnel related to operations, airworthiness, and maintenance of aircraft are licensed by statute. Government authorities consider registration or licensing an instrument for controlling and regulating the professionals. This paper is primarily focused on licensing and approval of different categories of aeronautical engineers. It discusses the importance of the licensing of engineers in the aeronautical industry and presents a critical review of various licensing standards and practices, including the standard recommended by the International Civil Aviation Organisation (ICAO). This paper also argues that the license issued by a contracting state of the ICAO must be fully convertible in another state, because it is granted by a member state in conformance with the standards recommended by the ICAO.
\end{abstract}

Keywords: aeronautical, airlines, aviation, engineer, industry, professional, registration.

\section{Introduction}

Aviation and aeronautical engineering is a truly global industry, and it is experiencing exceptional growth. Consequently, aeronautical engineers and other related personnel frequently work in different countries. This industry is highly regulated and a major part of the aeronautical engineering workforce is required to be licensed or authorised by statute to carry out certain tasks related to an aircraft or aeronautical product. As a result, the personnel holding such a license or authorisation encounter difficulties when they move to another country to perform similar tasks, because the other country may not recognise the licenses they hold. Consequently, they need to convert their licence before starting their professional work in that country. This could be a complex procedure in some countries. Licensing is primarily an 
instrument to control a profession, and it can sometimes be used as a tool to protect a trade in the current globalised aviation industry. This paper discusses the history of licensure, key licensing standards, and systems that are related to aeronautical engineering personnel and are currently in practice in a major part of the world. The paper primarily focuses on the standards developed and recommended by the $\mathrm{ICAO}^{1}$. It also suggests regulatory harmonisation of aeronautical industry activities at a global level as recommended by the ICAO.

\section{Overview of licensing}

Professional certification, trade certification, or a professional title is a designation earned by a person to certify that he or she is qualified to perform a specific job. Licensing engineers and other professionals protects the public by enforcing standards that restrict practice to appropriately qualified individuals (National Council... 2012a). Professional certifications are awarded by professional bodies. The difference between licensing and certification is that licensing is required by law, whereas certification is generally voluntary. Sometimes the word certification is also used for licensing. Certification or licensing may be perpetual, may need to be renewed periodically, or may be valid for a specific period of time. Regarding renewal of licenses, it is common that the individual must show evidence of continual learning, which is often termed as continuing education or current experience.

To elucidate the role of licensing in the flight safety chain, a state authorises an engineer to perform specific activities, which unless performed properly could jeopardise the safety of aviation operations (Convention... 2006; Civil... 2011). The licence or authorisation provides evidence that the holder has demonstrated competences meeting the standards that are recommended by the ICAO.

The first regulation to control a profession was established in Europe in the $12^{\text {th }}$ century by King Roger of Normandy, who decreed that doctors must present proof of competency before being allowed to practice medicine (Old... 1911). Similarly, the first licensing law governing the practice of engineering was enacted by Wyoming in 1907 (National Council... 2012b; National Society... 2012). With the formation of the ICAO in 1944 , the member states agreed to develop international standards for licensing aviation engineers and other personnel associated with civil aircraft (Convention... 2006). Consequently, the states were required to under-

\footnotetext{
1 The International Civil Aviation Organisation was formed in 1944 by the Chicago Convention as a specialised agency of the United Nations to promote the safe and orderly development of civil aviation. The ICAO develops international civil aviation standards, practices, and procedures for its 189 member countries known as Contracting States.
}

take the highest degree of uniformity in complying with the international standards (Wells, Wensveen 2004).

\section{Should all engineers be licensed?}

An engineer uses creativity, technology, and scientific knowledge to solve practical problems as a part of the profession of engineering. Engineers also apply established principles drawn from mathematics and science in order to develop economical solutions to technical problems while working on testing, production, design or maintenance of a product. The title engineer is normally used only by individuals who have an academic degree or equivalent work experience in one of the engineering disciplines. In some countries of continental Europe, the title is limited by law to people with an engineering degree. Similar laws exist in most US states and Canadian provinces (Edwards 2010). The debate about licensing the practicing engineers of all fields of the engineering profession has been going on for years. This began with a discussion regarding engineering and its status as a profession, and the argument has led to engineering as we know it today, which requires a standard four-year undergraduate degree in engineering discipline.

Is such a level of education sufficient for a status as a professional? A number of stakeholders may promote the idea of an educational requirement that goes beyond a four-year degree suggesting a professional school approach similar to the professions of law, medicine, and pharmacy, where an engineer would receive additional technical training or business training in order to meet the contemporary demands of the industry. Engineers who work in industry, government, education or private practice satisfy the identified characteristics regardless of whether or not they are licensed. All engineers should therefore be held responsible for protecting the public health, safety, and welfare, whether they provide services to the public directly or indirectly. Bringing all categories of engineers into the licensing fold may consequently be beneficial for both the public and the engineering profession.

\section{Licensing standards and systems in the aeronautical industry}

Aeronautical engineering is one of the fastest evolving disciplines. It has changed significantly since its beginning. Enormous development in aircraft designs, materials and interface systems, such as navigational computers, fly-by-wire flight and engine controls, etc. has enhanced the capability of the modern product significantly. Though the industry is heading towards deregulation, the engineering personnel related to design, manufacture, airworthiness and maintenance of an aircraft or aeronautical product are still controlled by means of licenses or task authorisation under relevant civil aviation regulations of the respective member state (Civil... 2008; 
Civil... 2011; Federal... 2012; Personnel... 2006). The licences or authorisations for aeronautical maintenance engineering personnel may be granted in various categories such as mechanical, avionics, or structural repairs with respect to a specific type or group of aircraft. By granting the licenses to individuals, a member state can ensure that maintenance of an aircraft is certified by people who are properly trained to meet ICAO standards. Civil aviation regulations have however evolved considerably in recent years as part of deregulation. A member state may consequently authorise an aircraft maintenance organisation to grant approvals to aircraft maintenance personnel employed by the organisation (Civil... 2011). Nevertheless, when a state authorises a maintenance organisation to grant such approvals, the employee must meet the standards mentioned in annex 1 of the ICAO SARPS (Personnel... 2006). Similar to the licensing of maintenance personnel, the professional aeronautical engineers who are involved in the certification of aircraft design, alteration, and modification are also granted specific authorisations related to the task by the civil aviation authority of the respective member state. For example, the civil aviation safety authority (CASA) of Australia grants specific authorisations to these personnel and it requires the applicant to hold a four-year undergraduate degree in a relevant engineering discipline (Civil... 2008). Under the regulations, no one other than the authorisation holder is allowed to certify these tasks.

These practices of licensing or authorising aeronautical engineering personnel carried out by respective member states not only are to ensure quality and safety of aircraft and aeronautical products, but also are required to meet ICAO standards. Under article 33 of the Chicago convention, SARPS adopted by the ICAO as minimum standards should be implemented by all member states and a license, certificate or authorisation granted by a state should be recognised by another member state (Convention... 2006). Similarly, the states are expected to use precise phrases and terminology in their national legislation as mentioned in the ICAO SARPS and also to indicate any departures from ICAO standards in the legislation. Furthermore, under article 38 of the convention, the states are also required to notify ICAO of differences between their national regulations and the SARPS (Convention ... 2006). Additionally, ICAO also advises the states to publish these differences in their aeronautical information publication.

Licenses and authorisations for aeronautical engineering personnel in the European Union (EU) are granted under the regulatory framework of the European Aviation Safety Agency (EASA), though the EU is not a member state of the ICAO and the EASA is not a regulatory authority of any such member state. Three levels of licenses known as $A, B$, and $C$ are granted to aeronautical maintenance personnel under the EASA system (Kingston... 2012). The levels primarily define the scope and privileges of the license. While the EASA claims that its license standard and system conforms to ICAO standards, the level $C$ license does not indicate any relation to the standard of aircraft maintenance personnel license mentioned in annex 1 of the ICAO SARPS. The EASA system projects this level as a maintenance management category of the license, but the ICAO annex 1 standard does not have any provision for such a category (Personnel... 2006). A reduction in the time period allocated for aircraft type training courses has also been noticed under the EASA system. For example, for a typical widebody transport aircraft, such as a Boeing 777, B1 and B2 license training course is being completed within a span of 35 days at training schools in Germany under EASA system approval (Lufthansa... 2010). A typical training course of such scope used to consume more than 60 days to complete in the past. It seems to be a dilution of the standard, but a detailed academic investigation is required to establish this. Although the FAA of the USA does not grant licenses or authorisation to aeronautical engineering personnel in conformity with ICAO standards, it divides them in three broad categories known as certificated mechanics, repairmen, and engineers to carry out relevant engineering and maintenance tasks (Federal... 2012). The US authority also grants approvals known as inspection authorisation to engineering personnel to certify certain tasks, such as major alteration or modification of an aircraft. These approvals are granted for a similar purpose by most member states of the ICAO, and they more or less meet the required standards, even though the procedural instruments differ significantly across the states. Nevertheless, this study of various licensing or authorisation systems of aeronautical engineering personnel suggests that harmonisation of the systems is possible. It also leads one to believe that a fully convertible licensing system under the ICAO regime would be beneficial for all stakeholders in the contemporary globalised aeronautical industry.

\section{Discussion and analysis}

Under current practices, licensing is not mandatory for all engineers in the aeronautical engineering field, and only the personnel who certify certain tasks related to aircraft or aeronautical products are required by statute to be licensed or authorised. Nevertheless, licensing is becoming increasingly significant in deregulated or privatised industry to ensure the safety of aircraft and the flying public. Heightened public attention concerning aircraft safety in commercial aviation also focuses on licensing and the competency standards of aeronautical engineering personnel. Engineering practices in the 
industry are constantly changing and the activities that are exempted today may eventually move into a practice area requiring a license. This may also be beneficial to the personnel. For example, $74 \%$ of aeronautical engineers in Canada believe that licensing provides professional recognition and broadens their career (Engineers... 2009). In the present era of cost cutting and lean engineering processes, the licensing of personnel is an instrument to assure the quality of the product, thereby ensuring the safety of the flying public. The current trend of deregulation in the industry may also influence the licensing system or standards. There is a growing concern within the industry that if the status of engineering personnel is eroded in any way, the safety of the aircraft will be affected. This will ultimately cause the loss of lives. On the negative side, the licensing approach may be viewed as limiting the number of qualified engineers or reducing competition, which could benefit the engineers who are already licensed. Nevertheless, the primary purpose of licensing engineers is quality assurance, which subsequently improves the safety of aircraft and the public.

The priority in the aviation field is safety, and it may be improved by keeping risks at an acceptable level. Creating technical standards and licensing at every appropriate level related to aeronautical engineering personnel could be a major step in accomplishing this. However, in complex aeronautical operations, such as aircraft maintenance, safety cannot be achieved by standards alone. It requires the on-going support of social engineering and an organisational structure committed to training, human factors, accountability reviews, and risk management processes. For example, two methods of standardising the competencies of aeronautical maintenance personnel, state licensing and company approval, exist in the industry around the world. Under the licensing system, a contracting state conducts related technical examinations and grant a license to the candidate provided the candidate meets other requirements, such as technical experience. The state is responsible for ensuring that the candidate possesses the required competencies before he or she is granted a license. In the company approval system, the organisation substantiates that the required competencies are met, and it maintains the assessment system. As a result, the organisation grants company approval to the candidate, and this approval is valid primarily for the organisation that issued it. The state in this case monitors and audits the training and assessment system managed by the organisation. Consequently, the procedures and competency standards may vary from one organisation to another, and that may create difficulties harmonising standards at the national and international level. Most states support licensing as superior to the company-managed approval model. Ac- cording to J. Haas, it is believed that a company approval system does not guarantee the required quality and independence due to economic pressure (Haas 2009).

However, neither of these models completely addresses the accountability requirements of all categories of aeronautical engineering personnel involved in the design, manufacture, airworthiness, and maintenance of aircraft, because only the key personnel are licensed or approved under the systems. The manufacturing sector especially requires attention, and the engineers involved in this sector may also be considered for licensing similar to the aircraft maintenance industry instead of registration, because the registration of professional engineers is mandatory in some jurisdictions, but voluntary in others. For example, a professional engineer is required by statute to be registered with the Board of Professional Engineers Queensland, if the engineer provides professional engineering services in Queensland State of Australia (National Engineering... 2012c). Conversely, the other states do not have such requirements and registration with the National Engineering Registration Board (NERB) of Australia is voluntary. The introduction of licensing in this sector of aeronautical engineering may enhance the individual accountability of the engineers and consequently improve flight safety in the current trend of lean manufacturing and low cost operations. Furthermore, a comprehensive approach of bringing the personnel under a state licensing system will also augment the harmonisation of international standards and the regulatory framework in the aeronautical manufacturing industry amongst the contracting states. This will eventually benefit the globalised aviation industry.

In the foregoing debate regarding the mutual recognition of the licenses and authorisations of aeronautical engineering personnel by member states of the ICAO, it can be inferred that the concept of mutual recognition may be advantageous for all. It will improve the movement of the personnel between member states, and it will also boost the body of available intellectual knowledge in the public domain. It is widely believed by the aeronautical community that the policy of non-acceptance of licenses or authorisations granted by another member state is more related to protecting trade than standards.

\section{Conclusion}

The complexity and global nature of the aeronautical engineering industry has encouraged the standardisation and licensing of engineering personnel. Licensing of the personnel has been introduced as a tool for controlling and regulating their functions and responsibilities to ensure safety of aircraft and aeronautical products. A major portion of the aeronautical engineering workforce must therefore be licensed or authorised by law. As a result, engineering personnel experience difficul- 
ties in practicing their profession in different countries, because they are required to be licensed in that country to perform similar tasks. This is mostly viewed as protection of trade rather than standards. This study has discussed the history of licensing, licensing standards, and various categories of licensed aeronautical engineering personnel. It has been argued that there is a need to license aeronautical engineering personnel in the aircraft manufacturing sector in a way similar to the aircraft maintenance industry to improve flight safety and the quality of aeronautical products. The paper has also explored relevant SARPS of the ICAO and subsequent approaches of major member states.

\section{References}

Civil Aviation Safety Authority [online]. 2008. Advisory letter to authorised persons: Information to applicants for design approval authorisations [cited 12 March 2012]. Available from Internet: http://www.casa.gov.au/wcmswr/_assets/ main/airworth/ap/alap/alap200801.pdf

Civil Aviation Safety Authority [online]. 2011. Manual of Standards. Part 145 [cited 09 March 2012]. Available from Internet: http://www.comlaw.gov.au/Details/F2011C00688

Convention on International Civil Aviation. 2006. $9^{\text {th }}$ ed. Montreal: International Civil Aviation Organization.

Edwards, J. 2010. Licensed and certified: professional licensing and certification can lead to a higher profile, more prosperous career [online], [cited 21 March 2012]. Available from Internet: http://www.graduatingengineer.com/articles/20060919/Licensed-and-Certified

Engineers Canada and Canadian Council of Technicians and Technologists [online]. 2009. Engineering and technology labour market study: trends in licensure and certification [cited 06 October 2011]. Available from Internet: http:// www.engineerscanada.ca/etlms/media/54879Trends $\% 20$ in\%20Licensure\%20and\%20Certification.pdf, accessed October 06, 2011.

Federal Aviation Administration [online]. 2012. Certification: airmen other than flight crew members. Part 65. [cited 12 March 2012]. Available from Internet: http://ecfr.gpoaccess. gov/cgi/t/text/text-idx?c=ecfr\&sid=eb13f71f115ccdc491187 185a85f9130\&tpl=/ecfrbrowse/Title14/14cfr65_main_02.tpl

Haas, J. 2009. Harmonizing occupational regulation in the EU transport sector: institutions, participants, and outcomes, in Proceedings of 9th European Sociological Association Conference. Lisboa, Portugal.

Kingston University [online]. 2012. Categories of license and the routes to gaining them [cited 06 October 2011]. Available from Internet: http://www.kingston.ac.uk/undergraduatecourse/aircraft-engineering-2013/how-do-i-become-alicensed-aircraft-engineer.html

Lufthansa Technical Training. Course description: B777-200/300 (GE 90). EASA Part-66 B1 \& B2 theoretical. 2010. Frankfurt: Lufthansa Technical Training.

National Council of Examiners for Engineering and Surveying [online]. 2012a. Licensure [cited 15 March 2012]. Available from Internet: http://www.ncees.org/Licensure.php, accessed March 15, 2012.

National Council of Examiners for Engineering and Surveying [online]. 2012b. The history of NCEES: a timeline of events [cited 12 March 2012]. Available from Internet: http://www. ncees.org/About_NCEES/The_history_of_NCEES.php
National Engineering Registration Board [online]. 2012c. Registration as an RPEQ [cited 03 April 2012]. Available from Internet: http://www.engineersaustralia.org.au/nerb/ registration-rpeq

National Society of Professional Engineers [online]. 2012d. Licensure [cited 06 February 2012]. Available from Internet: http://www.nspe.org/Licensure/WhyGetLicensed/lic_why_ advantages.html

Old and Sold [online]. 1911. Medical School at Salerno, [cited 21 March 2012]. Available from Internet: http:// www.oldandsold.com/articles $11 /$ medicine-11.shtml

Personnel Licensing. 2006. $10^{\text {th }}$ ed. Montreal: International Civil Aviation Organization.

Wells, A. T.; Wensveen, J. G. 2004. Air Transportation: A Management Perspective. $5^{\text {th }}$ ed. Belmont: Thomson Learning, Inc. 